\title{
Metodologia de abate de girinos de rã-touro para obtenção de filés de cauda e subprodutos não comestíveis*
}

\section{Bullfrog tadpoles slaughtering methodology to obtain tail fillets and non-edible by-products}

Andre Muniz Afonso, ${ }^{* *}$ Pâmela Carvalho de Almeida, ${ }^{* * *}$ Sântila Antunes Cardoso Bravo, ${ }^{* * *}$ Jasmim Valéria Arcanjo Araújo, ${ }^{* * *}$ Eliane Teixeira Mársico, ${ }^{* *}$ Carlos Adam Conte-Júnior, ${ }^{* *}$ Mônica Queiroz de Freitas, ${ }^{* *}$ Sergio Borges Mano**

\begin{abstract}
Resumo
O objetivo do presente trabalho foi estabelecer uma metodologia para abate de girinos, com foco na obtenção de filés de cauda para a produção de alimentos e da parte não comestível para a fabricação de farinha animal. As operações de abate foram

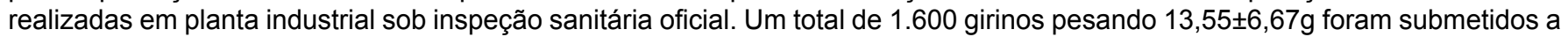
um jejum de 24 horas e em seguida coletados e transportados até a planta industrial, onde foram transferidos para caixas plásticas para depuração. As etapas tecnológicas de abate foram pré-insensibilização, lavagem, inspeção, decapitação e corte de cauda, produção dos filés de cauda, lavagem, embalagem da cauda e da parte não comestível, selagem, pré-resfriamento, congelamento rápido, estocagem e distribuição. O rendimento da parte não comestível foi de $73,49 \pm 5,51 \%$ em relação ao peso total, enquanto o rendimento dos filés de cauda representou $26,51 \pm 5,51 \%$ do peso total. O método desenvolvido mostrou-se eficaz para a obtenção dos produtos propostos, com bom rendimento porcentual para ambas matrizes obtidas.
\end{abstract}

Palavras-chave: carne de rã, carnes exóticas, Lithobates catesbeianus, tecnologia de abate.

\begin{abstract}
The aim of this study was to establish a methodology for slaughter tadpoles, focusing on obtaining tail fillets for the production of food and non-edible parts for the manufacture of animal feed. Slaughter operations were performed in an industrial plant under official sanitary inspection. A total of 1,600 tadpoles weighting $13.55 \pm 6.67 \mathrm{~g}$ were subjected to fasting for 24 hours and then collected and transported to the industrial plant, where they were transferred to plastic boxes for depuration. Slaughter technology steps were pre-stunning, cleaning, inspection, decapitation and tail cutting, production of tail fillets, cleaning, non-edible part and tail packaging, sealing, precooling, quick freezing, cold storage and distribution. The yield of non-edible part was $73.49 \pm 5.51 \%$ relative to the total weight, while the yield of fillets tail represented $26.51 \pm 5.51 \%$ of the total weight. The developed method was effective for obtaining the proposed products with good yield percentage for both.
\end{abstract}

Keywords: Exotic meats, Frog meat, Lithobates catesbeianus, Slaughter technology.

\section{Introduction}

The world market of frogs can be divided into three categories: production of frog legs for consumption, considered the prime objective in a frog farm; production of live adult frogs for export, usually for the resident oriental community in countries like the United States and Canada; and production of live frogs for education and research, used in laboratories, research centers, schools and universities. Also, the main consumers or importing countries are the United States, France, Canada, Belgium, Italy, Spain, Holland, Switzerland, China and Japan (Altherr et al., 2011; FAO, 2013).

In this panorama, the European continent is among the world's largest consumer, with a volume of imports from 8,000 to 10,000 tons of frog legs annually, where about $50 \%$ of this value goes directly to France, where the culinary wrapping the frog meat is traditional and well diversified (Neveu, 2004). In Latin America frog meat consumption is restricted or even related to consumers with high purchasing power (Weichert et al., 2007; Vega, 2011).

Internationally, frogs are included in the market category of fish and their meat is the main product of the frog culture, commonly known as raniculture. This contains all the essential amino acids for humans, has a high biological value, low calorie and hypoallergenic, besides having high digestibility. Like the fish meat has high moisture and essential minerals such as calcium, which is available in higher concentrations than milk products (Brasil, 1997; Cribb et al., 2013).

Traditionally, the frogs are slaughtered and their meat is frozen, being commonly sold in plastic packaging containing whole

\footnotetext{
${ }^{*}$ Recebido em 27 de março de 2015 e aceito em 7 de junho de 2016.

**Programa de Pós-graduação em Higiene Veterinária e Processamento Tecnológico de Produtos de Origem Animal - Faculdade de Veterinária, Universidade Federal Fluminense. Rua Vital Brazil Filho, n. 64, Niterói, Rio de Janeiro, Brasil (CEP 24320-340).

***Faculdade de Veterinária, Universidade Federal Fluminense.

Author e-mail adress: andremunizafonso@gmail.com
} 
carcass or only the lower thigh ("frog legs"). These business presentations historically encounter resistance by consumers, mainly by female audience, for their unattractive appearance. Thus, new forms of marketing emerged to try to break these barriers to consumers and also with the aim of adding greater commercial value (Weichert et al., 2007; Afonso, 2012).

The frog meat consumer has an average purchasing power, is instructed and increasingly more demanding, factors that leads to a differentiated market product, with better quality and lowest price relative (Moura, 2003; Weichert et al., 2007). Corroborating these authors, Ash et al. (2010) in a recent article called "Feeding the Future", say crops faster, leading to lower consumption of meat and more consumption of nutritious foods, should emerge in the coming years.

The facilities for the production of tadpoles are easier to be built and managed and requires poor initial investment and maintenance costs. In addition, the development time can be shortened to two months, corresponding to one third of the production cycle of frogs, which leads to an increase of production per square meter of area and higher working capital per year (Afonso et al., 2011).

To ensure the safety of products and byproducts of the frog, good management practices and good manufacture procedures should be applied from the breeding of animals to their own transformation into food for human consumption (Brasil, 2001; FAO/WHO, 2010; FAO, 2012).

Despite the need for the development of new and unconventional sources of protein, few studies undertaken to standardize techniques and procedures for the slaughter of exotic animals, being restricted to only game animals, mainly with regard to inspection (USDA, 2015; U.S. Department of Commerce, 2015).

In this context, the aim of this study was to establish a methodology for tadpole's slaughtering, focusing on obtaining tail fillets for food production and non-edible parts for the manufacture of animal feed.

\section{Material and methods}

The development of the tadpole's processing operations occurred in an industrial processing plant, with federal sanitary inspection (SIF). First, the bullfrog's tadpoles (Lithobates catesbeianus) were reared in earthen ponds following the basic management established for bullfrog's commercial farming in Brazil (CRIBB et al., 2013). After 60 days the tadpoles were weighting $13.55 \pm 6.67 \mathrm{~g}$ and the great majority belongs to stage 40 , as described by Gosner (1960). A total of 1.600 animals were used in the process ${ }^{1}$.

The slaughter process (Figure 1) was subdivided into two major steps, the pre-slaughter steps, which comprehends the procedures until the animals reaches the processing plant (fasting, harvesting and transportation); and the slaughter procedure itself, from depuration to distribution. The fasting process occurred 24 hours before the slaughtering, by the suspension of the feeding in earthen ponds - composed by a diet containing both commercial ration (levels of guarantee $45,69 \%$ of carbohydrates; $30,4 \%$ of crude protein; $12,5 \%$ of moisture; $7,67 \%$ of ashes; and $3,74 \%$ of crude fat) and natural plankton and constant replacement of the water.

The harvesting occurred in the next day, by the early morning, when earthen ponds were slowly depleted as the tadpoles were being harvested by small fishnets. After the harvesting, the tadpoles were kept in plastic bags, filled with tap water, and were transported inside plastic boxes to the industrial plant by small non-refrigerated trucks. The air temperature was $27 \pm 1^{\circ} \mathrm{C}$ and the distance from the frog farm to the industrial plant was $9.1 \mathrm{~km}$, which has taken 8 minutes to cover.

After the transportation, the animals were put in $1 \mathrm{~m}^{3}$ plastic box filled with potable water, for depuration. This process lasts for 8 hours and the water was changed four times to remove the maximum quantity of organic material. The following procedure was the pre-stunning, characterized by the replacement of $50 \%$ of the water in the box by potable thin ice. This stunning method is named thermonarcosis or ice slurry immersion and the minimum time preconized for their efficacy was 20 minutes. Also, liquid chlorine was put in the box to reach a concentration of five parts per million $(5 \mathrm{ppm})$ to avoid exogenous contamination.

The tadpoles were, individually, cleaned in flowing hyperchlorinated water $(5 \mathrm{ppm})$ and placed on a pre-sanitized stainless steel table for visual inspection. After that, with a sharp knife, the body and the tail were separated at body terminus and the animal was decapitated (Figure 2). The decapitation process completes the process of pre-stunning as according to international animal welfare practices (Van de Vis et al., 2003). The tail received a special cut in dorsal and ventral parts to obtain a fillet without the tail fins. Before packaging, both tail fillet and non-edible part were submitted to another cleaning in flowing hyperchlorinated water to remove residual blood. After individual packaging, the polyvinyl chloride packs (PVC) were sealed with a sealing machine and put in a stainless steel box with potable water and ice for precooling. This procedure helped to keep low temperatures until freezing. After that, the cooler tray was filled with the pre-cooled packs and put in a freezing chamber with forced air cooling system for two hours at $-25^{\circ} \mathrm{C}$. At the end, the packs were stored in a cold storage chamber at $-18^{\circ} \mathrm{C}$, being ready for distribution.

To evaluate the different percentage of yield of both products tail fillets and non-edible part - after the sealing, 80 packages were weighted in an electronic scale with a precision interval of $0.001 \mathrm{~g}$.

${ }^{1}$ Ethics Committee on Animal Experiments - Universidade Federal Fluminense (protocol number 573). 


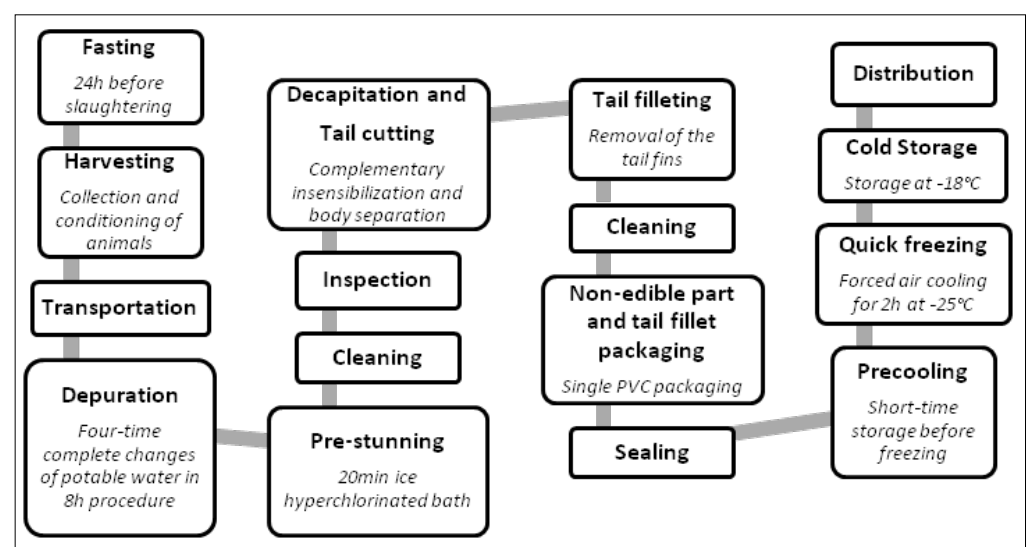

Figure 1: Flowchart for the processing of tadpoles.

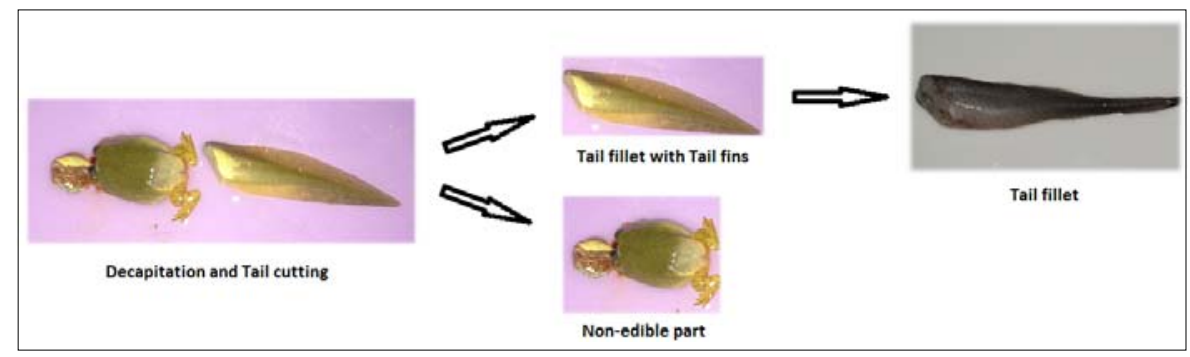

Figure 2: Tadpole's non-edible part and tail fillet obtainment.

\section{Results and discussion}

The production of food under sanitary inspection, using the right tools and good manufacture procedures in specific processing plants is in accordance with the minimal requirements for food safety. The segment of fish and fishery technology must be supported by prerequisite programs based on good hygienic practice or as required by the competent authority (BRASIL, 2007; Codex Alimentarius, 2013). The facilities used in the present study offered the best conditions for the development of the technique.

The method of slaughter and processing operation for bullfrog tadpoles proposed in this study was efficient for obtaining non-edible parts and frozen tail fillets when compared to the methodology proposed to obtain frog legs and fish and fishery products (Codex Alimentarius, 2011; 2013). The total processing time, just after pre-stunning to quick freezing step was 2 minutes.

The pre-slaughter steps settled for this study - fasting, harvesting and transportation - and the first slaughter step - depuration avoids welfare and technologic problems, by preventing faecal contamination, stress and short-time products' shelf life (Poli et al., 2005; Brasil, 2007; Vargas et al., 2013; Lines and Spence, 2014).

According to Lines and Spence (2014), specific welfare concerns are associated with some species. The pre-stunning step (ice slurry immersion) used in the study agrees with national laws prevailing in the slaughter of aquatic organisms (Brasil, 2000). In contrast, Van de Vis et al. (2003) consider the immersion in an ice slurry an inhumane method for slaughtering Atlantic salmons, gilt-head seabreams and eels. Nevertheless, they reported that this method, in average, showed that self-initiated behavior and visual evoked responses (VERs) were lost after 5 minutes when the water was $0.8 \pm 0.2^{\circ} \mathrm{C}$. According to the European Food Safety
Authority (2009), the ice slurry procedure used as stunning method kills trout by asphyxia; thereby is not considered as a humane method for killing fish. Kestin et al. (2002), studied trouts, salmons, seabreams, eels and other fishes and concluded that decerebration was an effective method of stunning by inhibiting self-initiated behavior, represented by swimming and equilibrium. The present study shows no self-initiated behavior in tadpoles by combining the two methods, ice slurry immersion (named pre-stunning) and decapitation (decerebration). As described by Cribb et al. (2013) the bullfrog's tadpoles naturally possesses three types of breathing habits - by lungs, by gills and by skin - thus the process could not be considered as an asphyxiation. The time stated for ice baths was 20 minutes, which was more than twice when compared to the other studies (Kestin et al., 2002; Van de Vis et al., 2003; European Food Safety Authority, 2009). As settled by Codex Alimentarius (2011), the killing should be done immediately after stunning in such a manner that either the head is severed from the body or the brain is destroyed by pithing. Poli et al. (2005) stated that the combination of various killing methods together may be a more satisfactory strategy for both animal welfare and product quality.

The cleaning and inspection (ante-mortem) steps were important to ensure the good manufacture procedures during the slaughtering. Many risks, including potential zoonotic diseases, are avoided if a correct food inspection planning is applied to the different sections in the fish food-chain industry (Brasil, 2007; Codex Alimentarius, 2011; 2013; Knoff et al., 2013; Marrone et al., 2014).

According to Cribb et al. (2013), in the frog slaughtering process, before the packaging step the carcass is submitted to an esthetic retail and complete removal of blood clots. In the present study, the tail filleting procedure was performed to increase the good quality, to avoid contamination and to expand shelf life of the tadpoles' fillets.

Bykowski and Dutkiewicz (1996) and Muscolino (2012) stated that packaging should protect the product from contamination and prevent it from spoilage, also it extends their shelf life, facilitates their distribution and display, gives greater consumer appeal and facilitates the display of information. The packaging step settled in that study also prevented the formation of freeze burns in the fillets.

Ansari (1999) stated that precooling enables the refrigeration engineer to select a smaller size of heat transfer equipment for cold storage and Mai et al. (2012) showed the importance of precooling of fresh fish for both air and sea transportation. In the present study, precooling was used to secure the preservation of the fillets and non-edible products until the quick freezing took place.

The steps of quick freezing and cold storage were directly in accordance with Johnston et al. (1994) and Codex Alimentarius (2013), which stated that the quick freezing process enables the 
fish and fishery products to be reduced from a temperature of $0^{\circ} \mathrm{C}$ to $-5^{\circ} \mathrm{C}$ in two hours or less and then kept in storage for $-18^{\circ} \mathrm{C}$ or lower temperatures to be well preserved until the distribution.

The non-edible parts weighted $10.49 \pm 5.48 \mathrm{~g}$, which corresponds to $73.49 \pm 5.51 \%$ of the total weight, while the tail fillets weighted $3.58 \pm 1.72 \mathrm{~g}$, which corresponds to $26.51 \pm 5.51 \%$ of the total weight. The tadpole noble part (tail fillets) do not differ significantly to the frog noble part (frog legs), which corresponds to $30 \%$ of the total weight (Afonso, 2012).

Another aspect to be considered is the cost of production, which for the frog, primarily for its carnivorous post-metamorphic habit, represents about $70 \%$ of the total cost (CRIBB et al., 2013). The same percentage can be found in other carnivorous fish, like the rainbow trout, which has better performance filleting, reaching $61 \%$ of the total weight (Rasmussen, 2001). However, comparing the bullfrog tadpole to a fish of the same omnivorous diet habits, such as tilapia, their fillet yield values range from 30.5 to $33.4 \%$, therefore, they are not statistically different (Garduño-Lugo et al. 2003; 2007).
The rearing of tadpoles can be made in two or three months, while the total rearing time for frogs lasts for six to eight months (Cribb et al., 2013), thus could be an advantage for the exploitation of tadpoles for food purposes. Furthermore, all the steps set out for tadpoles slaughtering flowchart can usually be performed on fish industrial plants under official inspection without the need for flow or infrastructure changes (Codex Alimentarius, 2013), so there is a huge potential for the development of food products using the bullfrog tadpole as food matrix.

\section{Conclusions}

With the adoption of traditional steps used for slaughtering frogs and fishes from aquaculture, the methodology proposed for slaughtering tadpoles proved to be efficient for the production of tail fillets and non-edible products from earthen ponds reared tadpoles. Also, the total processing time was short and a good final yielding for tail fillets for the production of food and non-edible parts for the manufacture of animal feed were attained.

\section{Acknowledgments}

The authors are grateful to Conselho Nacional de Desenvolvimento Científico e Tecnológico (CNPq) and to Fundação Carlos Chaga Filho de Amparo à Pesquisa do Estado do Rio de Janeiro (FAPERJ) for the financial support. We would also like to thank the Cooperativa Regional de Piscicultores e Ranicultores do Vale do Macacu e Adjacências Ltda. (COOPERCRÃMMA) for providing the facilities for this work.

\section{References}

AFONSO, A.M. 2012 Ranicultura se consolida com cadeia produtiva operando em rede interativa. Revista Visão Agrícola, Piracicaba, n. 11, p. 33-35.

AFONSO, A.M.; NUNES, E.S.C.L.; GUIMARÃES, C.F.M.; CUNHA, F.L.; DE LA TORRE, C.A.L.; MÁRSICO, E.T.; CONTEJÚNIOR, C.A.; MANO, S.B. 2011 Composição centesimal e rendimento da musculatura caudal da rã-touro americana na fase larval. In: CONBEP, 17. Belém. Anais... Recife: Associação Brasileira de Engenharia de Pesca, n. 25, p.1-4.

ALTHERR, S.; GOYENECHEA, A.; SCHUBERT, D.J. 2011

Canapés to extinction: The international trade in frog's legs and its ecological impact.(Eds). Munich (Germany), Washington, D.C. (USA), p. 20.

ANSARI, F.A. 1999 Finite difference solution of heat and mass transfer problems related to precooling of food. Energy Conversion \& Management, v. 40, p. 795-802.

ASH, C.; JASNY, B.R.; MALAKOFF, D.A.; SUGDEN, A.M. 2010

Feeding the future. Science, v. 327, p. 797.

BRASIL. Instrução Normativa n.3, 17/01/2000, Regulamento Técnico de Métodos de Insensibilização para o Abate Humanitário de Animais de Açougue. Brasília, 2000, 7 p.

BRASIL. Regulamento da Inspeção Industrial e Sanitária de Produtos de Origem Animal - RIISPOA. Aprovado pelo Decreto n. 30.691 de 29/03/1952, alterado pelos Decretos n. 1.255 de 25/06/1962; n. 1.236 de 02/09/1994; n. 1.812, de 08/02/1996; e n. 2.244 de 04/06/1997, Brasília, 1997, 5 p.

BRASIL. Manual de Procedimento para Implantação de Estabelecimento Industrial de Pescado. Ministério da Agricultura, Pecuária e Abastecimento / Secretaria Especial de Aquicultura e Pesca, Brasília, 2007, 112 p.
BRASIL. Resolução RDC n. 12, de 02/01/2001 - Regulamento Técnico sobre Padrões Microbiológicos para Alimentos. Brasília, 2001, 48 p.

BYKOWSKI, P.; DUTKIEWICZ, D. Freshwater fish processing and equipment in small plants fao fisheries circular no. 905 fiiu/ c905, 1996. Available at: < http://www.fao.org/docrep/w0495e/ w0495e00.htm>. Accessed in: may 10, 2016.

CODEX ALIMENTARIUS. Code of hygienic practice for the processing of frog legs - CAC/RCP 30-1983, Editorial corrections 2011, 14p. Available at: <http://www.codexalimentarius.org/input/ download/standards/130/CXP_030e.pdf>. Accessed in: July 11, 2014.

CODEX ALIMENTARIUS. Code of practice for fish and fishery products - CAC/RCP 52-2003, Amendment 2013, 238p. Available in: <http://www.codexalimentarius.org/download/standards/10273/ CXP_052e.pdf>. Accessed in: July 11, 2014.

CRIBB, A.Y.; AFONSO, A.M.; MOSTÉRIO, C.R.F. Manual técnico de ranicultura. Rio de Janeiro: EMBRAPA, 2013, 76 p.

EUROPEAN FOOD SAFETY AUTHORITY. 2009 Species-specific welfare aspects of the main systems of stunning and killing of farmed fish: rainbow trout. The EFSA Journal, v. 1013, p. 1-55.

FAO. Food and Agriculture Organization of the United Nations. Fisheries and Aquaculture Department. Cultured Aquatic Species Information Programme: Rana catesbeiana. Available in: <http:// www.fao.org/fishery/culturedspecies/Rana_catesbeiana/en>. Accessed in: November 15, 2013.

FAO. The State of World Fisheries and Aquaculture. Rome: FAO, 2012, 230 p.

FAO/WHO. 2010. Food and Agriculture Organization of the United Nations / World Health Organization. Food Stande lards Programme. Codex Alimentarius Commission. Procedural Manual, 19 ed. Rome: FAO/WHO, 192 p. 
GARDUÑO-LUGO, M.; GRANADOS-ALVAREZ, I.; OLVERANOVOA, M.A.; MUÑOZ-CÓRDOVA, G. 2003 Comparison of growth, fillet yield and proximate composition between Stirling Nile tilapia (wild type) (Oreochromis niloticus, Linnaeus) and red hybrid tilapia (Florida red tilapia $\times$ Stirling red $O$. niloticus) males. Aquaculture Research, v. 34, p. 1023-1028.

GARDUÑO-LUGO, M.; HERRERA-SOLÍS, J.R.; ANGULOGUERRERO, J.O.; MUÑOZ-CÓRDOVA, G; De La CRUZMEDINA, J. 2007 Nutrient composition and sensory evaluation of fillets from wild-type Nile tilapia (Oreochromis niloticus, Linnaeus) and a red hybrid (Florida red tilapia $\mathrm{x}$ red $O$. niloticus). Aquaculture Research, v. 38, p.1074-1081.

GOSNER, K.L. A simplified table for staging anuran embryos and larvae with notes on identification. Herpetologica, v. 16, p. 183190,1960

JOHNSTON, W.A.; NICHOLSON, F.J.; ROGER, A.; STROUD, G.D. 1994 Freezing and refrigerated storage in fisheries. FAO Fisheries Technical Paper, n. 340,

KESTIN, S.C; VAN DE VIS, J.W.; ROBB, D.H.F. 2002 Protocol for assessing brain function in fish and the effectiveness of methods used to stun and kill them. Veterinary Record, v. 150, p. 302-307.

LINES, J.A.; SPENCE, J. 2014 Humane harvesting and slaughter of farmed fish. Revue Scientifique et Technique de I'Office International des Epizooties, v. 33, n. 1, p. 255-264.

KNOFF, M.; SÃO CLEMENTE, S.C.; FONSECA, M.C.G.; FELIZARDO, N.N.; LIMA, F.C.; PINTO, R.M.; GOMES, D.C. Anisakidae nematodes in the blackfin goosefish, Lophius gastrophysus Miranda-Ribeiro, 1915 purchased in the State of Rio de Janeiro, Brazil. Acta Scientarum, v. 35, n. 1, p. 129-133, 2013.

MAI, N.T.T.; MARGEIRSSON, B.; MARGEIRSSON, S.; BOGASON, S. G.; SIGURGÍSLADÓTTIR, S.; ARASON, S. 2012 Temperature mapping of fresh fish supply chains - air and sea transport. Journal of Food Process Engineering, v. 35, p. 622-656.

MARRONE, R.; CAROSIELLI, L.; MANGIACOTTI, M.; CHIARAVALLE, E.; SMALDONE, G.; ANASTASIO, A. 2014 Monitoring of irradiated food products marketed in Italy and evaluation of electron spin resonance signal sensitivity of experimentally irradiated fish scales. Italian Journal of Food Safety, v. 3 (1603), p.73-77.

MOURA, O.M. A carne de rã como matéria-prima e seu uso em produtos derivados. Boletim do Instituto de Pesca, v. 34, p. 68-73, 2003.
MUSCOLINO, D.; GIARRATANA, F.; GIUFFRIDA, A.; PANEBIANCO, A. 2012 Inspective Investigation on Swordfish (Xiphias gladius) frozen Slices of Commerce: AnatomicalHistopatological Findings. Czech Journal of Food Science, v. 30 , n. 3, p. 206-210, 2012.

NEVEU, A. Edible frogs. In: SAFRAN, P. Fisheries and Aquaculture, 2004, v. 3. p. 305-322.

POLI, B.M.; PARISI, G.; SCAPPINI, F.; ZAMPACAVALLO, G. 2005 Fish welfare and quality as affected by pre-slaughter and slaughter management. Aquaculture International, v. 13, p. 29-49.

RASMUSSEN, R.S. Quality of farmed salmonids with emphasis on proximate composition, yield and sensory characteristics. Aquaculture Research, v. 32, p. 767-786, 2001.

UNITED STATES DEPARTMENT OF AGRICULTURE. 9 CFR Part 352, Subpart A - Exotic Animals. Available in: <https://www.law. cornell.edu/cfr/text/9/part-352/subpart-A > . Accessed in: January 12,2015

UNITED STATES DEPARTMENT OF COMMERCE. 50 CFR Part 260, Subpart A - Inspection and Certification of Establishments and Fishery Products for Human Consumption. Available in: <https://www.law.cornell.edu/cfr/text/50/part-260/subpart-A>. Accessed in: January 12, 2015.

VARGAS, R.C.V.; OLIVEIRA FILHO, P. R. C.; NATORI, M.M.; LIMA, C.G.; MACEDO VIEGAS, E.M. Evaluation of different stunning methods on aspects of animal welfare and meat quality of matrinxã (Brycon cephalus). Italian Journal of Food Science, v. 25, p. 255-262, 2013.

VEGA, R.C.V. Panorama General de la Ranicultura no Chile. In: ENAR, 12 \& TECHNOFROG, 3. Uberlândia. Anais... Uberlândia: Sociedade Brasileira de Ranicultura, p. 209-213, 2011.

VAN DE VIS, H.; KESTIN, S.; ROBB, D.; OEHLENSCHLÄGER, J.; LAMBOOIJ, B.; MÜNKNER, W.; KUHLMANN, H.; KLOOSTERBOER, K.; TEJADA, M.; HUIDOBRO, A.; OTTERÅ, H.; ROTH, B.; SØRENSEN, N.K.; AKSE, L.; BYRNE, H.; NESVADBA, P. Is humane slaughter of fish possible for industry? Aquaculture Research, v. 34, p. 211-220, 2003.

WEICHERT, M.A.; MELLO, S.R.P.; ESPINDOLA, L.M. O consumo de tilápias e rãs nas cidades do Rio de Janeiro e Niterói. Panorama da Aquicultura, Rio de Janeiro, v.17, n.102, p.37-41, 2007. 